\title{
How Explicit Listening Strategy Instruction Affects Listening Comprehension of Different Learners
}

\author{
Fatemeh Zarrabi \\ Faculty of Education, Monash University, Melbourne, Australia
}

\begin{abstract}
Listening has been a growing interest of EFL/ESL researchers and teachers in the last 50 years because the majority of learners view listening as one of the most problematic skills. Recently, there have been discussions on teaching listening with the emphasis on strategy instruction for better achievement in listening comprehension. Hence, the researcher designed this quantitative study to help learners overcome their problem. The aim of this experimental research is to investigate whether explicit instruction of listening strategies s listening skill of different learner types. The study was conducted in an English language academy in Iran with 135 high-Intermediate EFL participants for 10 sessions. A pre-/post-test design was selected for data collection. The results revealed that all learners showed a higher mean score in the post-test than the pretest but with a slight difference in improvement of listening comprehension of different learner types.
\end{abstract}

Index Terms - listening strategy instruction, listening comprehension, learner types

\section{INTRODUCTION}

As listening has been an important part of language programmes (Brown, 2006; Clement, 2007; Richards and Burns, 2012), some second language (L2) listening scholars argued that it should be taught in a more theoretically-informed manner in the classroom (Brown, 2006; Vandergrift, 2007). A conscious plan is needed in listening comprehension to deal with problems (like incomplete understanding) that a listener might encounter with while listening (Richards and Schmidt, 2007). The listeners are of different types and the teacher should take their types of learning into consideration. It makes learning easier when the learning material suits the student's learning style (Ehrman and Leaver, 2003). Learning styles refer to any individual characteristics of a learner which are their natural and preferred habits of learning (Reid, 1995). These different styles of learning result in different learner types. The interwoven of psychological, socio-cultural and educational backgrounds comprise learner types (Willing, 1993).

Although there is a profound research on listening strategy training, there is a dearth of research on its influence on the listening comprehension of different types of learners. Thus, this paper will explain whether explicit instruction of listening strategies has any statistically significant impact on the listening comprehension of different learner types.

\section{LITERATURE REVIEW}

Richards and Schmidt (2007) defined listening comprehension as the process of understanding speech in a first or second language. The study of listening comprehension processes in L2 learning focuses on the role of individual linguistic units, the listener's characteristics, context or the situation, background knowledge and the topic. It therefore includes both 'bottom-up' and 'top-down' processing (Vandergrift, 2007). Although the importance of teaching listening comprehension was underemphasized in traditional language teaching approaches, more recent approaches emphasize the role of listening in language competence development (Field, 1998; Liu, 2009; Richards and Burn, 2012; Zhang, 2012; Graham and Santos, 2015; Jacobsen, 2015). The researchers also believe that teaching listening in the initial stages of second or foreign language learning should gain more attention. Oxford (2011) defines language learning strategies as the techniques that are utilized by learners to improve the use of target language information. L2 listening research in recent years has focused on understanding listening strategies and how second language learners manipulate them to cope with their difficulties while listening. Listening strategy has become an integral part of L2 listening research (Graham, et al., 2008). Research in L2 listening has been increasingly directed to recognize facilitative strategies and clarify listener's mental processes (Cross, 2012). The interest in listening comprehension strategies has evolved in a number of research studies (Graham and Macaro, 2008; Siegel, 2012; Jacobsen, 2015). Listening strategies according to Celce-Murcia and Olshtain (2000), is classified by how the listener processes the input. Vandergrift (2007) categorized listening strategies into three macro groups: cognitive, meta-cognitive, and social/affective strategies. Cognitive strategies are used by language learners to process, store, and recall new information (Goh, 2000). Two broad types of cognitive strategies have been the subject of L2 listening research: bottom-up and top-down. Bottom-up strategies are text based. They involve word-for-word translation, adjusting the rate of speech, repeating the oral text, and focusing on prosodic features of the text. While top-down strategies are 
listener based. They include predicting, inferencing, elaborating, and visualization (Mendelsohn, 2001; Vandergrift, 2007). Meta-cognitive strategies are management techniques by which learners control their learning through planning, directed attention, selective attention, monitoring, and evaluating (O'Malley and Chamot, 1990; Vandergrift, 2007). Modifying was also added to metacognitive subcategories by Rubin (2011). As Oxford (2011) puts, the conscious use of meta-cognitive strategies helps learners get back their attention when it is lost. However, learners do not use metacognitive strategies very frequently despite the importance of self-monitoring and self-evaluation. Social/affective strategies have been classified into two categories: cooperation and confidence building. The former is used for explanation and clarification and the latter one for encouraging oneself to be able to think positively and to be relaxed (Vandergrift, 2007; Liu, 2010). In a number of research studies, it has been demonstrated that skilled learners use more strategies than their less-skilled counterparts. In addition, there were differences in the types of strategies skilled and less-skilled learners applied (Guan, 2014). Empirical studies have found that an important distinction between skilled and less skilled L2 listeners lies in their use of meta-cognitive strategies (e.g., O'Malley and Chamot, 1990; Goh, 2000; Vandergrift, 2004). Vandergrift (2007) discovered that skilled listeners utilized twice as many meta-cognitive strategies as their less-skilled counterparts. According to research studies by Berman (2003), O’Malley et al. (1990) and Young (1997), listening strategies include three different steps: pre-listening, while listening (identifying main ideas, note taking, processing details, determining the relationships of ideas, guessing vocabulary from context, identifying pronoun referents), and post-listening strategies. Based on a research by O'Malley et al. (1990) and Young (1997), six listening strategies are inferencing, elaboration, self-monitoring, summarization, self-evaluation, and toleration of ambiguity.

On the other hand, there are various learner types with different preferences and teachers should be aware of these differences while teaching each language skill since the students learn more effectively if the teaching method is in consistent with their type of learning (Flowerdew and Miller, 2010). The main focus of research studies was learning styles and preferences in the mid-1920s (e.g. Willing, 1993; Reid, 1995). These different performances of learners on learning activities while they were taught via the same instructor and the same teaching methodology became an important issue and concern for the researchers (Reid, 1999). Therefore, a great body of research has been conducted in the area of learning styles since then. For example, Chen (2009) conducted a research study to investigate the relationship between perceptual learning style preferences, grade level, and language learning strategies among Taiwanese high school students and concluded that teachers should be aware of the differences in their students and present the information in a way that appeals to every individual. In another study, Chen and Hung (2012) investigated the impact of personality type on learning style and language learning strategies. There were 364 Taiwanese senior high school students as the participants of the study. Based on their conclusion, there is a significant relationship between personality type, learning style, and language learning strategies.

Mehrpour and Motlagh (2015) investigated how motivation and attitude affect English language learning, learning style, and gender. 154 Iranian EFL learners participated in the study. The result of their research study indicated that the majority of learners were either auditory or visual and there was not a significant correlation between learners' language proficiency and learning style. There are some other researchers who have investigated the effect teaching writing skill on the writing skill of different learner styles (e.g. Young, 2010; Sahragard and Mallahi, 2014) and concluded that there is a strong correlation between teachers' teaching methodology and achievement of different learners with various style of learning preferences.

All of the aforementioned researchers have measured the participants' learning style preferences through use of either Willing (1993) or Reid (1999) model. Willing (1993) proposed a model for different types of learners, categorizing them into four main groups, namely concrete, analytical, authority-oriented, and communicative learners. Reid (1999) has classified learner types in three main different groups: cognitive, personality, and sensory learning styles in which there are some sub-categories. In this research study, sensory learning style is taken into account which is divided into four groups named as visual, auditory, kinaesthetic, and tactile learner types.

\section{StATEMENT OF THE PROBLEM}

Nowadays, listening has gained widespread attention of EFL learners worldwide. Thus, learners are in need of some strategies to help them overcome their listening obstacles. In such a case, teachers are the only ones who can guide their students by teaching them listening strategies. From the literature, it is obvious that there has been lots of studies on learning styles, teaching methodologies, and listening strategy instruction separately (e.g. Graham and Macaro, 2008; Graham and Santos, 2015; Jacobsen, 2015; Zhang, 2015; Zarrabi, 2016), but to the best of author's knowledge there is no research on the effect of explicit instruction of listening strategies on the listening comprehension skill of different learner types. Therefore, the current study is designed to shed more light on the issue of "Do all learner styles benefit from listening strategy instruction?" and fill the gap in this area.

\section{METHODOLOGY}

The current study sought to examine how explicit teaching of listening strategies influences the listening comprehension of different learner types. The literature review showed that while many studies have investigated the 
listening strategies and how skilled and less skilled learners apply them, little or no research has examined the impact of listening strategy instruction on the listening comprehension of different learner types. Regarding the mentioned purpose, one basic research question was raised:

Q1: Does explicit instruction of listening strategies have any statistically significant impact on the listening comprehension skill of different Iranian intermediate learner types?

Participants

150 high-intermediate Iranian EFL students in 14 (10-12 students per class) classes of a private English language institute were chosen as the participants of the study. Different listening strategies were taught to the subjects through various listening tasks other than the ones in their regular curriculum (English Result Intermediate). The subjects were all female language learners aged from 15 to 40 and with Persian as their L1. After homogenization of the participants through FCE proficiency test, twenty subjects were disqualified and brought the total number of the subjects down to 135.

\section{Instrumentation}

Two sets of materials were applied in the current research study: firstly for the purpose of instruction (instructional materials) and, secondly, for measuring participants' abilities (tests).

- Instructional materials

Listening strategy instructions were designed and presented in ten sessions (each session $=90$ min) within course requirements.

- Coursebook

The subjects in this study were all taught the same through "English Result Series" intermediate level by Mark Hancock \& Annie McDonald (2009) as their course book. Furthermore, the sources from which the listening tasks for intermediate EFL learners were selected and applied in listening strategies instructions, were "Q Skills for Success 4 (Listening and Speaking)" by Freire and Jones (2011), "Open Forum 2 (Academic listening and speaking)" by Blackwell and Naber (2006), and "Tactics for listening (Advanced)" by Richards (2011).

- Listening strategies

Iranian EFL/ESL students are studying English for different purposes; some love learning it, some want to be prepared to take standardized English tests or to study at a university abroad, and some for migration. Regarding the above mentioned fact, listening is one of the vital skills which should be taught and is not something that is gained naturally (Nunan, 2002). Some researchers have categorized listening strategies into different groups. For example, Berman (2003) has listed listening strategy in three main steps which are: (a) pre-listening strategies, (b) while listening strategies, and (c) post-listening strategies. In addition, other researchers' listening strategies categorization such as O’Malley et al. (1989) and Young (1997) were implemented and instructed to the participants in this study.

- Tests

In this study, four sets of test were applied: FCE test, listening comprehension pre-test, Reid's learner type questionnaire, and listening comprehension post-test. The pre-tests and post-tests had four parts: two parts to test listening for details and two parts to test listening for the main ideas. Each of these tests is discussed in more details below.

- FCE test

First Certificate of English (FCE) language proficiency test is employed in this study for homogenizing the participants. FCE consists of four sections to evaluate the students' listening, speaking, reading, and writing in English language. The FCE proficiency test in this study had four main parts including three-part reading with 30 items, twopart writing, four-part use of English with 42 items, and the last part dealt with listening with 30 items. The recommended time for the test was 225 minutes. Firstly, the test was piloted with a group of 26 participants similar to the target sample (as the control group) prior to its main administration.

- Listening Comprehension Pre-test

A listening comprehension pre-test was taken from the participants to measure their listening comprehension in the first session. The listening pre-test was derived from the Cambridge website. It was checked regarding IF and ID. The test consisted four parts including: eight short pieces of monologue or conversation with 3-option multiple-choice items focusing on detail, gist, opinion, purpose, topic, and relationship; one monologue or conversation with 10 sentence completion items focusing on understanding of specific information given in the piece; five short monologues with five matching items with the same focus as part 1; and one interview or discussion with seven 3-option multiple-choice items focusing on understanding of detail, gist, opinion, and attitude.

- Perceptual Learning Style Preference Questionnaire (Reid, 1995)

Reid questionnaire (1998) consists of 30 items which identifies learners' preferred medium of learning among four different learning styles including visual, auditory, tactile/haptic, and kinaesthetic. In this questionnaire, every item is followed by five options including; $\mathrm{SA}=$ Strongly Agree, $\mathrm{A}=$ Agree, $\mathrm{U}=$ Undecided, $\mathrm{D}=\mathrm{Disagree}$, and $\mathrm{SD}=\mathrm{Strongly}$ Disagree. The participants were asked to fill out this questionnaire.

- Listening Comprehension Post-test

A listening comprehension post-test with the same qualifications as the listening comprehension pre-test was given to the participants to examine the effect of the researcher's methodology on them. 


\section{Procedure}

The main purpose of the current study was to investigate the impact of listening strategy instruction on the listening comprehension of different learner types. Firstly, all the available one hundred and fifty participants participated in the first phase of the study, which was homogenization of the participants. Prior to the study, the subjects were informed about the main goal of the study.

For the purpose of having homogenized participants, they were initially tested using the FCE test. Those participants who scored above the mean were chosen as the main participants of the study. Accordingly, the number of participants decreased to 135 . Then, to gain information about the participants' learner types, they were asked to fill Reid's perceptual learning styles questionnaire.

The participants received 10 sessions of listening strategies instruction. Brief explanation of strategies which were developed by different researchers such as Young (1997), O’Malley et al. (1989), Celece-Murcia and Olshtain (2000), and Berman (2003) were written on paper. These printouts were given to the students on the first session but each strategy was taught and emphasized in each separate session. In each session, the researcher went through the course book just as usual and then she asked the participants to use the presented listening strategies in listening parts. By doing so, the researcher got feedback from the participants and made sure whether they understood these listening strategies and their objectives. The other nine sessions had just the same procedure as the first, and one of the listening strategies was highlighted in every single session. At the end, the obtained data was analysed to test the proposed research question of the study.

Design

This study had a pre-test/post-test design, and the participants were chosen through non-random selection. As one of the prerequisites of a true experimental design which is random assignment of participants is not met, this study has a quasi-experimental design. This study had one dependent variable which was listening comprehension ability. The independent variable was the instruction: explicit teaching of listening strategies and learner type was considered as the moderator variable. Furthermore, control variables of the study were language proficiency level and gender because the participants were all female and at the intermediate level. The participants were first homogenized through using FCE exam. Then, they had a listening comprehension pre-test and in the succeeding sessions, they went through the instruction sessions and after that, a listening comprehension post-test was administered in the last session.

\section{Data Analysis AND Results}

This study was designed to examine how explicit teaching of listening strategies influences listening comprehension of Iranian intermediate learner types. First, it initiates with the results of testing assumptions, then, the statistical procedures used for the measurement of the aforementioned variables will be elaborated. Finally, the data will be analysed in order to answer the research question.

The Result of Testing Assumptions

There are four assumptions which need to be considered before running parametric tests (Field 2013): the participants should perform independently, homogeneous variances of the groups should be met, normal distribution of data is important, and an interval scale should be used for measuring the data. All four above mentioned assumptions are met in this study. As displayed in Table 1 the ratios of skewness and kurtosis over their respective standard errors are within the ranges of +/- 1.6 (Field 2013).

TABLE 1.

NORMALITY OF THE TESTS

\begin{tabular}{|c|c|c|c|c|c|c|c|c|}
\hline \multirow[t]{2}{*}{ Learner Code } & & \multicolumn{2}{|l|}{$\mathrm{N}$} & \multicolumn{3}{|l|}{ Skewness } & \multicolumn{2}{|l|}{ Kurtosis } \\
\hline & & Statistic & Statistic & Std. Error & Ratio & Statistic & Std. Error & Ratio \\
\hline \multirow{3}{*}{ Auditory } & FCE & 24 & -0.518 & 0.472 & -1.097 & -0.621 & 0.918 & -0.676 \\
\hline & Pretest & 24 & 0.167 & 0.472 & 0.354 & -1.097 & 0.918 & -1.195 \\
\hline & Posttest & 24 & -0.317 & 0.472 & -0.672 & -1.174 & 0.918 & -1.279 \\
\hline \multirow{3}{*}{ Kinaesthetic } & FCE & 53 & -0.420 & 0.327 & -1.284 & -0.561 & 0.644 & -0.871 \\
\hline & Pretest & 53 & 0.432 & 0.327 & 1.321 & 0.152 & 0.644 & 0.236 \\
\hline & Posttest & 53 & -0.078 & 0.327 & -0.239 & -0.501 & 0.644 & -0.778 \\
\hline \multirow{3}{*}{ Tactile } & FCE & 15 & -0.590 & 0.580 & -1.017 & -0.257 & 1.121 & -0.229 \\
\hline & Pretest & 15 & -0.875 & 0.580 & -1.509 & -0.298 & 1.121 & -0.266 \\
\hline & Posttest & 15 & -0.832 & 0.580 & -1.434 & -0.540 & 1.121 & -0.482 \\
\hline \multirow{3}{*}{ Visual } & FCE & 43 & -0.148 & 0.361 & -0.410 & -0.710 & 0.709 & -1.001 \\
\hline & Pretest & 43 & 0.556 & 0.361 & 1.540 & -0.077 & 0.709 & -0.109 \\
\hline & Posttest & 43 & 0.214 & 0.361 & 0.593 & -0.485 & 0.709 & -0.684 \\
\hline
\end{tabular}

The Results of Piloting the FCE Proficiency Test

A one-way ANOVA was run to prove that the participants are homogeneous regarding their level of general language proficiency prior to the main study. Based on the results in Table 2, the Levene's F-value of 1.32 is not significant $(\mathrm{P}=$ $0.270>0.05)$. 
TABLE 2.

LEVENE'S TEST OF HOMOGENEITY OF VARIANCES; PROFICIENCY TEST

\begin{tabular}{llll}
\hline Levene Statistic & df1 & df2 & Sig. \\
\hline 1.324 & 3 & 131 & 0.270 \\
\hline
\end{tabular}

The results in Table 3 shows $(\mathrm{F}(3,131)=0.648, \mathrm{P}=0.585>0.05 ; \omega 2=0.008)$ which is a weak effect size. Therefore, it is concluded that there are no significant differences between the mean scores of the four leaner types on the proficiency test. Thus, it can be claimed that they are all in the same level of general language proficiency prior to the main study.

TABLE 3.

TWO-WAY ANOVA PROFICIENCY BY LEARNER TYPES

\begin{tabular}{|c|c|c|c|c|c|}
\hline Sum of Squares & & Df & Mean Square & $\mathrm{F}$ & Sig. \\
\hline Between Groups & 132.506 & 3 & 44.169 & 0.648 & 0.585 \\
\hline Within Groups & 8926.798 & 131 & 68.143 & & \\
\hline Total & 9059.304 & 134 & & & \\
\hline
\end{tabular}

As it is displayed in Table 4, the mean scores of the auditory, kinaesthetic, tactile/haptic and visual groups on the proficiency test are $82.38,81.75,82.13$ and 79.91 respectively (Figure 1).

TABLE 4.

DESCRIPTIVE STATISTICS PROFICIENCY BY LEARNER TYPE

\begin{tabular}{|c|c|c|c|c|c|c|c|c|}
\hline & \multirow[t]{2}{*}{$\mathrm{N}$} & \multirow[t]{2}{*}{ Mean } & \multirow[t]{2}{*}{ Std. Deviation } & \multirow[t]{2}{*}{ Std. Error } & \multicolumn{2}{|c|}{$95 \%$ Confidence Interval for Mean } & \multirow[t]{2}{*}{ Minimum } & \multirow[t]{2}{*}{ Maximum } \\
\hline & & & & & Lower Bound & Upper Bound & & \\
\hline Auditory & 24 & 82.38 & 9.160 & 1.870 & 78.51 & 86.24 & 62 & 95 \\
\hline Kinaesthetic & 53 & 81.75 & 8.642 & 1.187 & 79.37 & 84.14 & 60 & 94 \\
\hline Tactile & 15 & 82.13 & 7.800 & 2.014 & 77.81 & 86.45 & 66 & 93 \\
\hline Visual & 43 & 79.91 & 7.338 & 1.119 & 77.65 & 82.17 & 65 & 93 \\
\hline Total & 135 & 81.32 & 8.222 & 0.708 & 79.92 & 82.72 & 60 & 95 \\
\hline
\end{tabular}

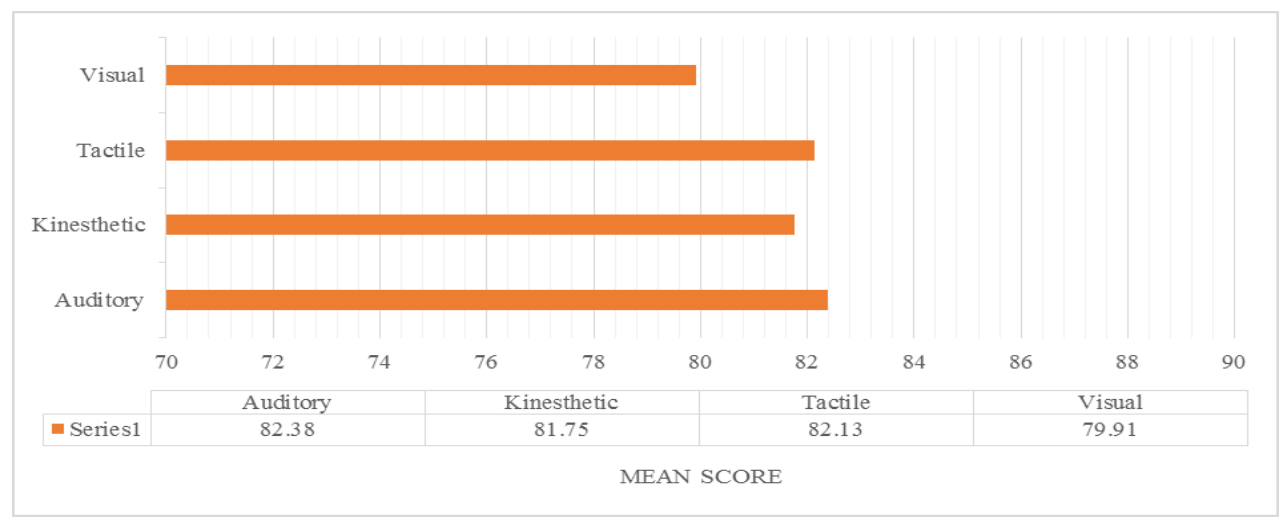

Figure 1. FCE Proficiency Test by Learner Types

The Results of Piloting the Listening Comprehension Pre-Test

A one-way ANOVA was run to investigate the listening comprehension skill of different learner types (auditory, kinaesthetic, tactile/haptic, and visual) by taking a pre-test of listening comprehension before the intervention. Table 5 demonstrates that the Levene's F-value of 0.771 is not significant $(\mathrm{P}=0.512>0.05)$.

TABLE 5.

LEVENE'S TEST OF HOMOGENEITY OF VARIANCES; LISTENING COMPREHENSION PRE-TEST

\begin{tabular}{llll}
\hline Levene Statistic & df1 & df2 & Sig. \\
\hline 0.771 & 3 & 131 & 0.512 \\
\hline
\end{tabular}

A two-way ANOVA was run to compare different learner types in the listening comprehension pre-test. As it is shown in Table $6(\mathrm{~F}(3,131)=0.104, \mathrm{P}=0.958>0.05 ; \omega 2=0.02)$, there is a weak effect size. Thus, it is concluded that there is no significant difference between the mean scores of the four leaner types on the listening comprehension pretest. Thus, it is claimed that the participants' level of listening comprehension ability were the same before the intervention.

TABLE 6.

TWO-WAY ANOVA PRE-TEST OF LISTENING COMPREHENSION BY LEARNER TYPES

\begin{tabular}{llllll}
\hline Sum of Squares & & df & Mean Square & F & Sig. \\
\hline Between Groups & 1.444 & 3 & 0.481 & 0.104 & 0.958 \\
\hline Within Groups & 606.289 & 131 & 4.628 & & \\
\hline Total & 607.733 & 134 & & & \\
\hline
\end{tabular}


According to the information in Table 7, the mean scores of the auditory, kinaesthetic, tactile/haptic, and visual groups on the listening comprehension pre-test are 11.71, 11.55, 11.87, and 11.58 respectively (Figure 2).

TABLE 7.

DESCRIPTIVE STATISTICS PRE-TEST OF LISTENING COMPREHENSION BY LEARNER TYPE

\begin{tabular}{|c|c|c|c|c|c|c|c|c|}
\hline & \multirow[t]{2}{*}{$\mathrm{N}$} & \multirow[t]{2}{*}{ Mean } & \multirow[t]{2}{*}{ Std. Deviation } & \multirow[t]{2}{*}{ Std. Error } & \multicolumn{2}{|c|}{ 95\% Confidence Interval for Mean } & \multirow[t]{2}{*}{ Minimum } & \multirow[t]{2}{*}{ Maximum } \\
\hline & & & & & Lower Bound & Upper Bound & & \\
\hline Auditory & 24 & 11.71 & 1.899 & 0.388 & 10.91 & 12.51 & 9 & 15 \\
\hline Kinaesthetic & 53 & 11.55 & 2.366 & 0.325 & 10.89 & 12.20 & 6 & 18 \\
\hline Tactile & 15 & 11.87 & 1.846 & 0.477 & 10.84 & 12.89 & 8 & 14 \\
\hline Visual & 43 & 11.58 & 2.096 & 0.320 & 10.94 & 12.23 & 8 & 17 \\
\hline Total & 135 & 11.62 & 2.130 & 0.183 & 11.26 & 11.98 & 6 & 18 \\
\hline
\end{tabular}

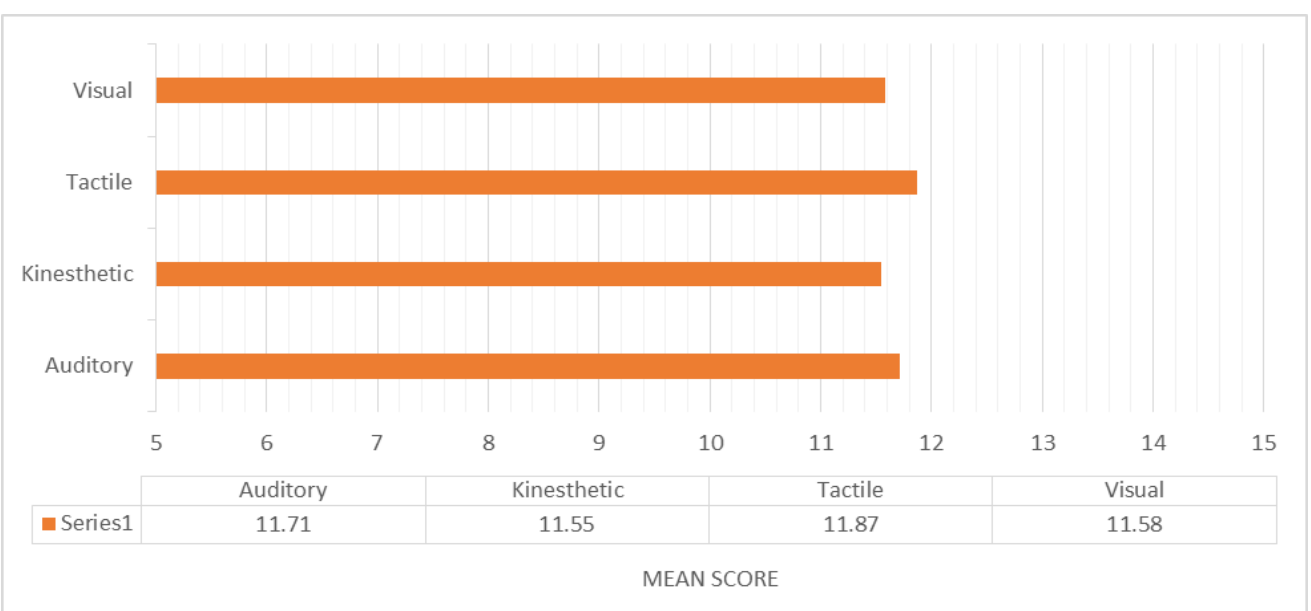

Figure 2. Pre-test of Listening Comprehension by Learner Types

In order to investigate whether explicit instruction of listening strategies has statistically significant effect on the listening comprehension of different Iranian intermediate learner types or not, the researcher needed to run a pairedsamples t-test to compare the students' mean scores on the pre-test and post-test of listening comprehension. The results of the paired-samples t-test $(\mathrm{t}(134)=61.42, \mathrm{P}=0.000<0.05, \mathrm{R}=0.98)$ represents a large effect size and indicates that there is a significant difference between the mean scores of the students on the pre-test and post-test of listening comprehension (Table 8).

TABLE 8.

PAIRED-SAMPLES T-TEST PRE-TEST AND POST-TEST OF LISTENING COMPREHENSION

\begin{tabular}{|c|c|c|c|c|c|c|}
\hline \multicolumn{4}{|c|}{ Paired Differences } & \multirow[t]{3}{*}{$\mathrm{t}$} & \multirow[t]{3}{*}{$\mathrm{df}$} & \multirow[t]{3}{*}{ Sig. (2-tailed) } \\
\hline Mean & Std. Deviation & Std. Error Mean & $\begin{array}{l}\text { 95\% Confidence Interval of the } \\
\text { Difference }\end{array}$ & & & \\
\hline & & & Lower & & & \\
\hline 12.281 & 2.323 & 0.200 & 11.886 & 61.420 & 134 & 0.000 \\
\hline
\end{tabular}

The students after receiving explicit instruction of listening strategies showed a higher mean score on the post-test (M $=23.90)$ than the pre-test $(\mathrm{M}=11.62)$ (Table 9, Figure 3$)$.

TABLE 9.

DESCRIPTIVE STATISTICS PRE-/POST-TEST OF LISTENING COMPREHENSION

\begin{tabular}{lllll} 
& \multicolumn{4}{c}{ DESCRIPTIVE STATISTICS PRE-/POST-TEST OF LISTENING COMPREHENSION } \\
\hline Pean & $\mathrm{N}$ & Std. Deviation & Std. Error Mean \\
\hline Pre-test & 23.90 & 135 & 2.687 & 0.231 \\
\hline
\end{tabular}

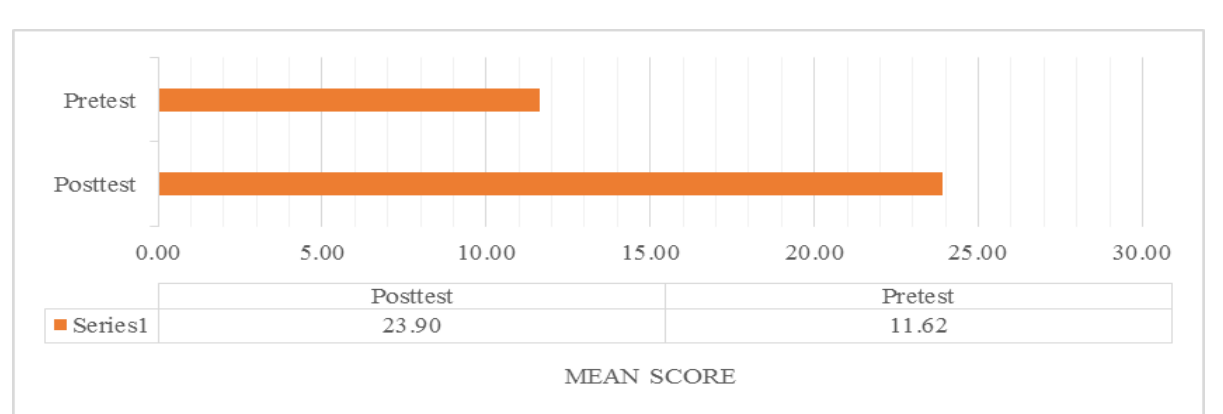

Figure 3. Pre-test and Post-test of Listening Comprehension 


\section{CONCLUSION AND IMPLICATIONS}

The aim of this study was to investigate the effect of explicit listening strategies instruction on the listening comprehension of different learner types. Based on the results and data collected, it is concluded that explicit instruction of listening strategies has statistically significant impact on the listening comprehension improvement of all EFL learner types. The outcome of this study also supports the findings of previous research (e.g. Graham and Macaro, 2008; Liu, 2009; Zhang, 2012; Guan, 2014; Graham and Santos, 2015; Jacobsen, 2015).

Therefore, this research has made significant contributions to the area of improving Learners' listening skill. For example, the EFL/ESL teachers are enlightened to consider how much different preferred ways of learning exist. As a result, a wide range of English teaching methods is required to make classes beneficial to all learner types. In addition, the results of this paper gave the teachers a wider vision about students' problematic skills which might be due to lack of their knowledge about strategies. Overall, the researcher also concluded that by raising strategy awareness of students for each skill, the teachers will make passive learners, active and independent learners.

Pedagogical Implications

The findings of this study provide implications for teacher education, teachers, and curriculum designers, as well as test designers. The study seems to endorse the notion of providing teachers with the necessary information about the effectiveness of listening strategies, the important role of learner styles in teaching methodology. The EFL/ESL teachers and syllabus designers are aware that there are different listening strategies as a basis in courses to design listening tasks with variety of questions. In addition, they should provide students with some tips about listening strategies in each unit. Furthermore, curriculum designers and teachers should consider the social, cultural aspects of language use, and their preferred ways of learning, knowledge, experiences, and individual learning differences that students bring to classes.

Suggestions for Further Research

As the participants of this study were female, the study can be replicated with male participants. It would be interesting to probe the effect of explicit instruction of listening on listening comprehension of language learners in other levels since the participants of the current study were all high intermediate EFL learners. Moreover, similar studies can be carried out to investigate the comparative effect of different listening strategies to find out which strategy is the most effective one. Furthermore, the focus of other studies can be shifted towards investigating the effect of explicit teaching of writing, reading, or speaking strategies on skills other than listening comprehension.

\section{REFERENCES}

[1] Berman, M. (2003). Advanced Listening, Listening Strategy Guide. Dynamic Education International, Inc. http://202.197.120.98/Downloads/LrnStrtg/str_002.pdf. (accessed 22/01/2013).

[2] Brown, S. (2006). Teaching Listening. New York: Cambridge University Press.

[3] Celce-Murcia, M., \& Olshtain, E. (2000). Discourse and context in language teaching. A guide for language teachers. Cambridge: Cambridge University Press.

[4] Chen, M.L. (2009). Influence of grade level on perceptual learning style preferences and language learning strategies of Taiwanese English as a foreign language learners. Learning and Individual Differences, Elsevier 19, 304-308.

[5] Chen, M.L., \& Hung, L.M. (2012). Personality type, perceptual style preferences, and strategies for learning English as a foreign language. Social Behaviour and Personality, 40.9, 1501-1510.

[6] Clement, J. (2007). The impact of teaching explicit listening strategies to adult intermediate- and advanced-level ESL university students. Retrieved from ProQuest Dissertations and Theses, UMI No. 3253098 (accessed 15/03/2013).

[7] Cross, J. (2012). Listening strategy instruction (or extensive listening?): A response to Renandya (2012). ELT World Online, 4, $1-6$.

[8] Derrry, S.J., \& Murphy, D.A. (1986). Designing systems that train learning ability: From theory to practice. Review of Educational Research, 56, 1-39.

[9] Ehrman, M.E., \& Leaver, B.L. (2003). A brief overview of individual differences in second language learning. System, 31, $313-$ 330.

[10] Field, A. (2013). Discovering Statistics Using SPSS (4th ed). London: SAGE Publications.

[11] Field, J. (1998). Skills and strategies: Towards a new methodology for listening. ELT Journal, 52.2, 110-18.

[12] Flowerdew, J., \& Miller, L. (2010). Learning Styles and Listening Strategies. Second Language Listening. Theory and Practice. Cambridge: Cambridge Uniersity Press.

[13] Goh, C.C.M. (2000). A cognitive perspective on language learners' listening comprehension problems. System, 28 , 55-75.

[14] Graham, S., \& Macaro, E. (2008). Strategy instruction in listening for lower-intermediate learners of French. Language Learning, 58.4, 747-783.

[15] Graham, S., \& Santos, D. (2015). Strategies for Second Language Listening: Current scenarios and improved pedagogy ( $1^{\text {st }}$ ed.), Palgrave MacMillan, Basingstoke.

[16] Graham, S., Santos, D., \& Vanderplank, R. (2008). Listening comprehension and strategy use: A longitudinal exploration. Elsevier, System, 36, 52-68.

[17] Guan, Y. (2014). The effects of explicit listening strategy instruction on the listening comprehension of English as a second language (ESL) community college students. ProQuest Dissertations and Theses (accessed 20/04/2015).

[18] Jacobsen, C. (2015). The impact of listening strategy instruction on the learning of English and an additional foreign language. Malaysian Journal of ELT Research, 11.1, 16-39. 
[19] Liu, Y.C. (2009). The utilization of listening strategies in the development of listening comprehension among skilled and lessskilled non-native English speakers at the college level. Retrieved from ProQuest Dissertations and Theses, UMI No. 3400780, (accessed 22/01/2013).

[20] Mehrpour, S., \& Motlagh, F.A. (2015). Investigating the effect of motivation and attitude towards learning English, learning style preferences and gender on Iranian EFL learners' proficiency. Research Papers in Language Teaching and Learning, 6.1, 144-160.

[21] Mendelsohn, D. (2001). Listening comprehension: We've come a long way, but... . Contact, 27, 33-40.

[22] Nunan, D. (2002). Listening in language learning. In J. C. Richards, and W. A. Renandya (eds.), Methodology in language teaching. Cambridge: Cambridge University Press, 238-41.

[23] O’Malley, J.M., \& Chamot, A.U. (1990). Learning strategies in second language acquisition. Cambridge: Cambridge University Press.

[24] O’Malley, J.M., Chamot, A.U., \& Kupper, L. (1989). Listening comprehension strategies in second language acquisition. Applied Linguistics, 10.4, 418-437.

[25] O'Malley, J.M., Chamot, A.U., \& Walker, C. (1987). Some applications of cognitive theory to second language acquisition. Studies in Second Language Acquistion, 9, 287-306.

[26] Oxford, R.L. (2011). Teaching and researching language learning strategies. Harlow, England: Longman.

[27] Reid, J. (1999). Affect in the classroom: problems, politics and pragmatics. In J. Arnold (Ed.). Affect in Language Learning. Cambridge: Cambridge University Press, 297-306.

[28] Richards, J.C., \& Burns, A. (2012). Tips for Teaching Listening: A Practical Approach. New York: Pearson Education.

[29] Richards, J.C., \& Schmidt, R. (2007). Longman dictionary of language teaching and applied linguistics (3 ${ }^{\text {rd }}$ ed.). London: Longman.

[30] Rubin, J. (2011). The study of cognitive process in the second language learning. Applied Linguistics, 2, 117-131.

[31] Siegel, J. (2012). Second language learners' perceptions of listening strategy instruction. Innovation in Language Learning and Teaching, 7.1, 1-18.

[32] Skehan, P. (1998). A Cognitive Approach to Language Learning. Oxford: Oxford University Press.

[33] Vandergrift, L. (2004). Orchestrating strategy use: Toward a model of the skilled second language listener. Language Learning, 53.3, 463-496.

[34] Vandergrift, L. (2007). Recent developments in second and foreign language listening comprehension research. Language Teaching, 40.3, 191-210.

[35] Willing, K. (1993). Learning Styles in Adult Migrant Education. Sydney: NSW Adult Migrant Education Service.

[36] Young, N. (1997). Teaching students how to learn: A language learning project. Papers from the 13th conference on English teaching and learning in R.O.C. (pp. 195-204). Taipei: The Crane Publishing Co.

[37] Zarrabi, F. (2016). The impact of listening strategy training on the meta-cognitive listening strategies awareness of different learner types. Journal of English Language Teaching, 9.5, 154-165.

[38] Zhang, Y. (2012). The impact of listening strategy on listening comprehension. Theory and Practice in Language Studies, 2.3, 625-629.

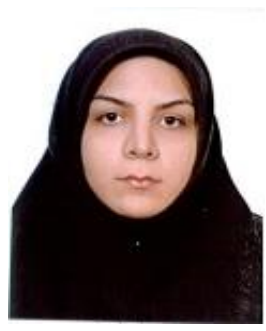

Fatemeh Zarrabi graduated in MA degree in Teaching English to Speakers of Other Languages (TESOL) in 2013. She started her PhD at Monash University, Melbourne, Australia in education (TESOL) in 2015. She has more than seven years English language teaching experience to EFL/ESL learners.

Her expertise is in the areas of English Language Teaching (ELT), TESOL, language teacher education, Language Learning Strategies (LLS), methodology in language teaching, and language testing. 